\title{
ANALISIS MENGENAI PROSTITUSI CYBER BAGI PARA PELAKU DAN BAGI PARA MUCIKARI DI INDONESIA
}

\author{
ANALYSIS OF CYBER PROSTITUTION FOR THE APPLICANTS AND FOR THE \\ PUCKERS IN INDONESIA
}

\author{
Hanuring Ayu \& Suparwi \\ Fakultas Hukum Universitas Islam Batik Surakarta \\ Email: hanuringayu@gmail.com \\ Diterima: 22 Mei 2019, Direvisi: 19 Juni 2019, Disetujui: 4 Juli 2019
}

\begin{abstract}
ABSTRAK
Tujuan penulisan ini untuk mengetahui tentang dasar hukum bagi penyedia jasa prostitusi dan bagi para pelaku prostitusi. Dalam penelitian ini termasuk ke dalam hukum normatif. Penelitian ini menggunakan pendekatan perundang-undangan. Ketentuan di dalam KUHP hanya dapat digunakan untuk menjerat penyedia jasa / germo/muncikari berdasarkan ketentuan Pasal 296, Pasal 297, jo. Pasal 506 KUHP: Orang yang menyediakan jasa pornografi sebagaimana disebutkan dalam Pasal 4 ayat (2) UU Pornografi Nomor 44 tahun 2008. Jika kata-kata atau tulisan dan gambar yang disiarkan oleh pelacur (prostitute) melalui media sosial memuat kecabulan atau eksploitasi seksual yang melanggar norma kesusilaan dalam masyarakat, maka pelacur (prostitute) tersebut dapat saja dijerat dengan Pasal 27 ayat (1) UU Nomor 11 Tahun 2008 tentang ITE jo. Pasal 45 UU Nomor 19 Tahun 2016 Tentang Perubahan UU No 11 Tahun 2008. Jika iklan yang dilakukan oleh pelacur (prostitute) tersebut disertai foto yang mengandung muatan pornografi, maka ia juga dapat dikenai pidana berdasarkan Pasal 8 jo. Pasal 34 UU Pornografi Nomor 44 Tahun 2008. Penegakan hukum tentang prostitusi cyber semakin sulit dilakukan karena ada sebagian masyarakat yang justru mendukung prostitusi cyber dengan menganggapnya sebagai komoditi bisnis. Bahkan ada paradigma pemikiran yang menganggap prostitusi cyber sebagai hal yang wajar dan diharapkan untuk segera dilegalisasikan.
\end{abstract}

Katakunci: prostitusi cyber, pelacur, mucikari

\section{ABSTRACT}

The purpose of this study is to find out about the legal basis for prostitution service providers and for perpetrators of prostitution. In this study included in normative law. In this study the authors used the method of regulation approach. Provisions in the Criminal Code can only be used to ensnare service providers / pimps / pimps based on the provisions of Article 296, Article 297, jo. Article 506 of the Criminal Code: People who provide pornographic services as referred to in Article 4 paragraph (2) of the Pornography Law No. 44 of 2008. If words or writings and images broadcast by prostitutes (prostitute) through social media contain obscenity or sexual exploitation in violation moral norms in society, the prostitute can be charged with Article 27 paragraph (1) of Law Number 11 Year 2008 concerning ITE jo. Article 45 of Law Number 19 Year 2016 Regarding Amendment to Law No. 11 of 2008. If the advertisement carried out by prostitutes is accompanied by photographs containing pornographic content, then he may also be subject to criminal sanctions under Article 8 jo. Article 34 of the Pornography Law No. 44/2008. Law enforcement on cyber prostitution is increasingly difficult because there are some people who actually support cyber 
prostitution by considering it as a business commodity. There is even a paradigm of thought that regards cyber prostitution as natural and expected to be legalized immediately.

Keywords: cyber prostitution, prostitutes, pimps

\section{PENDAHULUAN}

Kemajuan teknologi meningkatkan arus informasi antar negara, antar benua, bahkan antar bangsa sehingga perubahan budaya di Barat dengan cepat dapat diketahui di Timur. Perubahan budaya di Eropa dan Amerika dengan cepat dapat diketahui di Asia dan sebaliknya (Leden Marpaung, 1996, 06).

Perkembangan ilmu pengetahuan yang pesat turut mempengaruhi perkembangan kesusilaan. Jika dahulu orang membicarakan tentang seks telah dianggap tabu tetapi pada saat ini telah dibahas secara ilmiah dalam ilmu seksiologi. Pada beberapa majalah bahkan surat kabar harian telah dibahas tentang seks yang dimuat pada rubrik tanya jawab atau rubrik seksiologi.

Perkembangan "hak-hak asasi manusia" telah menitikberatkan hukum "menikmati seks" merupakan hak (right) orang dewasa sehingga hubungan seks yang dilakukan tanpa paksaan di sebagian negara di dunia merupakan perbuatan yang wajar (Leden Marpaung, 1996; 07)

Kemajuan teknologi informasi

yang demikian pesat, melahirkan teknologi digital yang mengakibatkan terjadinya keterpaduan ataupun konvergensi dalam perkembangan teknologi informasi, Media dan telekomunikasi. Semula masing masing teknologi tersebut seakan berjalan terpisah satu dengan yang lainnya, namun kini semua teknologi tersebut semakin menyatu.

Pada tahapan perkembangannya kemudian, modus operandi kejahatan bergerak maju seiring perkembangan peradaban manusia. Kejahatan dan eksistensi masyarakat menjadi "dua sisi mata uang" yaitu saling terikat. Sehingga Lacassagne mengatakan bahwa masyarakat mempunyai penjahat sesuai dengan jasanya (Agus Raharjo, 2002; 29).

Perkembangan teori-teori kejahatan juga berkembang signifikan akan tetapi tidak berarti kejahatan akan musnah dari permukaan bumi. Hal ini disebabkan kejahatan merupakan salah satu sifat fitrah manusia yang ada pada diri manusia dan terus mengalami perkembangan signifikan dengan perkembangan masyarakat itu sendiri. Hal ini hampir sejalan dengan apa yang dikemukakan oleh Freud yang menyatakan bahwa hasrat untuk merusak manusia sama kuatnya dengan hasrat untuk mencintai (Erich Frommm, 2000, $15)$.

Pendapat Freud mungkin benar adanya, akan tetapi argumentasi yang muncul kemudian adalah keseimbangan hasrat untuk merusak dan mencintai dapat dipengaruhi oleh lingkungan sekitarnya (faktor luar). Akan tetapi Lorenz dalam argumentasinya mengatakan bahwa keagresifan manusia merupakan insting yang digerakkan oleh sumber energi yang selalu mengalir dan tidak selalu akibat rangsangan dari luar. Jadi, dapat dikatakan bahwa destruksitivas (kejahatan) selalu ada pada diri setiap manusia, hanya bagaimana meninimalkan potensi yang secara kefitrahan ada pada setiap individu (Erich Frommm, 2000; 08).

Menyadari konsep psikologi yang ada pada setiap manusia, mutakhir bagaimanapun perkembangan teknologi informasi, maka akan semakin mutakhir pula bentuk dan modus individu melakukan kejahatan. Hal tersebut tidaklah mengherankan jika berangkat 
pada konsepsi tidak ada kejahatan tanpa masyarakat, komunitas atau masyarakat yang peduli terhadap teknologi informasi (internet) dengan netizen. Hal ini berarti dengan komunitas masyarakat tersendiri, maka kejahatan akan tercipta seiring timbul dan berkembangnya netizen itu sendiri (Maskun, 2013; 44).

Kejahatan atau tindak kriminal merupakan salah satu bentuk dari perilaku menyimpang yang selalu ada dan melekat pada tiap bentuk masyarakat, tidak ada masyarakat yang sepi dari kejahatan. Menurut Saparinah Sadli, perilaku menyimpang itu merupakan suatu ancaman yang nyata atau ancaman terhadap norma norma sosial yang mendasari kehidupan dan keteraturan sosial, dapat menimbulkan ketegangan individual maupun ketegangan sosial dan merupakan ancaman riil atau potensial bagi berlangsungnya ketertiban sosial. Dengan demikian kejahatan di samping merupakan masalah kemanusiaan ia juga merupakan masalah sosial (Barda Nawawi Arief dan Muladi, 1992; 148).

Terhadap masalah kemanusiaan dan kemasyarakatan yang tertua ini telah banyak usaha - usaha penanggulangan yang dilakukan dalam berbagai cara (Barda Nawawi Arief dan Muladi, 1992; 148). Upaya penanggulangan kejahatan sesungguhnya merupakan upaya terus menerus dan berkesinambungan selalu ada, bahkan tidak akan pernah ada upaya yang bersifat final. Dalam hal ini dimaksudkan ada upaya penanggulangan kejahatan tidak dapat menjanjikan dengan pasti bahwa kejahatan itu tidak akan terulang atau tidak akan memunculkan kejahatan baru. Namun demikian upaya itu tetap harus dilakukan untuk lebih menjamin perlindungan dan kesejahteraan masyarakat (Abdul Wahid dan M. Labib, 2005; 52).

Hukum merupakan komponen sistem sosial yang dianggap lebih efektif menyelesaikan probelm sosial berupa kejahatan di masyarakat. perubahan masyarakat dapat memicu perubahan kejahatan yang notabenenya mengikuti perkembangan masyarakat tersebut. Oleh karena itulah, hukum dalam masyarakat pun harus berubah mengikuti perkembangan masyarakat. Dialog antara perkembangan hukum dan perkembangan masyarakat dapat menjadi nilai pijakan perkembangan penanggulangan kejahatan di dalam berkembangnya masyarakat ( Budi Suhariyanto, 2013; 23).

Berkaitan dengan pembangunan di bidang teknologi, dewasa ini peradaban manusia dihadirkan dengan adanya fenomena baru yang mampu mengubah hampir setiap aspek kehidupan manusia, yaitu perkembangan teknologi informasi melallui internet (Dikdik M. Arief Mansur dan Elisatris Gultom, .2005; 84).

Bagi sebagian orang munculnya fenomena ini telah mengubah perilaku manusia dalam berinteraksi denga manusia lain, baik secara individu maupun kelompok. Di samping itu kemajuan teknologi tentunya akan berjalan bersamaan dengan munculnya perubahan perubahan di bidang kemasyarakatan. Perubahan perubahan tersebut dapat mengenai nilai nilai sosial. Kaidah-kaidah sosial, pola-pola perilakuan, organisasi, susunan lembaga lembaga kemasyarakatan, lapisan lapisan dalam masyarakat, kekuasaan dan wewenang interaksi sosial dan lain sebagainya (Soerjono Soekanto, 1980, 87).

Hal yang sama dikemukakan oleh Satjipto Raharjo pada saat menyatakan "dalam kehidupan manusia banyak alasan yang dapat dikemukakan sebagai penyebab timbulnya suatu perubahan di dalam masyarakat, tetapi perubahan dalam menerapkan hasil-hasil teknologi modern dewasa ini banyak disebut sebut sebagai salah satu sebab bagi terjadinya perubahan sosial (Satjipto Raharjo, 1980, 96). 
Kemajuan teknologi informasi khususnya media internet dirasakan banyak memberikan manfaat seperti dari segi keamanan, kecepatan, serta kenyamanan. Contoh sederhana dengan dipergunakannyya media internet sebagai sarana pendukung dalam pemesanan / reservasi tiket (pesawat terbang, kereta api), hotel, pembayaran tagihan telepon, token listrik, telah membuat konsumen semakin nyaman dan aman dalam menjalankan aktivitasnya. Konsumen tidak perlu keluar rumah dan antri untuk memperoleh layanan yang diinginkan karena proses pemesanan/revervasi dapat dilakukan di dalam rumah, kantor, bahkan di dalam kendaraan, begitu pula tingkat keamanan dalam bertransaksi relatif terjamin karena transaksi dilakukan secara online (Dewi Bunga, 2012, 6)

Bentuk kejahatan lainya seperti pornografi dalam berbagai jenis dengan mudah dapat dilihat di beberapa situs tertentu di internet. Masyarakat sangat merasakan keresahan akan aktivitas negatif di cyber space. Apalagi dengan beberapa pemberitaan di media massa tentang adanya prostitusi online (Dewi Bunga, 2012; 6). Kejahatan prostitusi cyber di Indonesia pernah terungkap pada bulan Mei 2003 dimana pada waktu itu Satuan Reskrimsus cyber crime Polda Metro Jaya berhasil menangkap mucikari cyber. Pelakunya adalah sepasang suami istri. Ramdoni alias Rino dan Yanti sari alias Bella. Prostitusi cyber ini adalah modus baru yakni dengan menawarkan wanita melalui sebuah alamat web (Dewi Bunga, 2012, 7). Pemilik web ini memajang foto -foto wanita tersebut dengan busana minim yang siap melayani customer. Para peminat hanya cukup menghubungi nomor HP para mucikari tersebut yang ditampilkan di halaman web, kemudian mucikari inilah yang mengantarkan pesanan ke kamar hotel atau ke apartemen sesuai dengan keinginan pelanggan (Sutarman, 2007; 67).

Cara yang dipakai mucikari untuk merekrut para penyedia jasa ini sangat beragam, tetapi biasanya mucikari ini merekrut atau mencari gadis belia yang berpenampilan manarik untuk dijadikan anak buahnya melalui layanan chatting dan sejenisnya yang beberapa tahun belakangan ini sudah menjadi trend di kalangan anak muda. Setelah mucikari berhasil merayu para gadis belia untuk menjadi anak asuhnya meraka biasanya akan langsung ditawarkan lewat website yang dikelola mucikari tersebut. Untuk bisa berkencan dengan gadis gadis muda ini, pada umumnya calon penyewa harus mendaftarkan diri dulu pada website dimana gadis-gadis tersebut dipamerkan. Calon penyewa akan mengisi formulir yang berisi nama, alamat, nomor telepon, dan lainnya. Setelah pendaftaran selesai, calon penyewa bisa langsung memilih gadis mana yang akan dikencani, lalu calon penyewa bisa mulai bernegosiasi harga. Setelah semua proses pendaftaran atau pemesanan selesai gadis pesanan akan diantarkan ke tempat yang telah disepakati (http://id.shuoong,com/internetand-technologies/website/1851387-

prostitusi-di-internet )

Seiring dengan semakin merambahnya penggunaan internet di Indonesia, aktivitas prostitusi cyber juga mengalami perkembangan. Para pelaku mulai menggunakan situs situs jejaring sosial seperti facebook untuk melancarkan aksinya. Facebook yang awalnya digunakan untuk pertemanan, kini dipergunakan untuk memasarkan transaksi seks. Istilah "bisa pakai" atau "bispak", cowok panggilan, cewek panggilan dan sejenisnya merupakan istilah yang dikenal dalam dunia maya khususnya prostitusi cyber untuk menunjukan bahwa individu yang bersangkutan menawarkan jasa seks (http://media.kompasiana.com/group/new- 
media/2010/04/1/bisnis-menjanjikanprostitusi-dalam-facebok/).

Aktivitas prostitusi cyber sangat meresahkan para netter dan para orang tua, apalagi aktivitas ini cenderung menjadikan anak anak sebagai objek eksploitasi seksual. Laporan UNICEF menyebutkan ada sekitar 2000.000 anak di seluruh dunia yang di eksploitasi secara seksual tiap tahunnya. Industri perdagangan anak ini ternyata meraup keuntungan hingga 12 milyar dollar per tahunnya (ILO). Di Indonesia sekalipun banyak gadis yang memalsukan umurnya, diperkirakan sekitar 30 persen pekerja seks komersil wanita berumur kurang dari 18 tahun. Bahkan ada beberapa yang masih berumur 10 tahun. Diperkirakan pula ada 40.000 - 70.000 anak menjadi korban eksploitasi seks dan sekitar 100.000 anak diperdagangkan tiap tahun (Dewi Bunga, 2012, 10).

Berdasarkan penjelasan di atas, masalah yang akan diangkat dalam penelitian ini adalah: 1) bagaimana jerat hukum bagi penyedia jasa prostitusi melalui media sosial. dan 2) bagaiamana jerat hukum bagi pelaku jasa prostitusi melalui media sosial.

\section{METODE PENELITIAN}

Dalam penelitian ini termasuk ke dalam hokum normatif yaitu penelitian hukum doktriner, juga disebut sebagai penelitian perpustakaan atau studi dokumen. Dikatakan sebagai penelitian perpustakaan ataupun studi dokumen disebabkan penelitian ini lebih banyak dilakukan terhadap data yang bersifat sekunder yang ada di perpustaaan (Suratman dan Philips Dillah, 2012, 51). Dalam penelitian ini penulis menggunakan metode pendekatan perundang undangan.

Bahan hukum primer adalah bahan hukum yang mempunyai otoritas (Zainuddin Ali, 2014, 47) Bahan hukum primer yang dipakai dalam penelitian ini terdiri atas :

1. Kitab Undang Undang Hukum Pidana

2. Undang Undang Nomor 19 tahun 2016 tentang perubahan Undang Undang Nomor 11 Tahun 2008 tentang ITE

3. Undang Undang Pornografi Nomor 44 Tahun 2008

Bahan hukum sekunder adalah bahan hukum yang memberi penjelasan terhadap bahan hukum primer, misalnya rancangan undang undang, hasil penelitian terdahulu dan lain sebagainya (Zainuddin Ali, 2014, 23). Bahan hukum sekunder yang dipakai dalam penelitian ini antara lain yaitu :

Metode pengumpulan data dengan metode penelitian kepustakaan. Data kepustakaan yang diperoleh melalui penelitian kepustakaan yang bersumber dari peraturan perundang undangan, buku -buku dokumen resmi, publikasi dan hasil penelitian (Zainuddin Ali, 2014, 107). Berdasarkan sifat penelitian ini yang menggunakan metode penelitian bersifat deskripsif analitis, analisis data yang dipergunakan adalah pendekatan kualitatif terhadap data primer dan data sekunder. Deskristif tersebut, meliputi isi dan struktur hukum positif yaitu suatu kegiatan yang dilakukan oleh penulis untuk menentukan isi atau makna aturan hukum yang dijadikan rujukan dalam menyelesaikan permasalahan hukum yang menjadi objek kajian (Zainuddin Ali, 2014, 107).

\section{HASIL DAN PEMBAHASAN Jenis Jenis Cyber Crime}

Jenis jenis kejahatan yang masuk dalam ketegori Cyber crime diantaranya adalah (Dikdik M. Arief Mansur dan Elisatris Gultom, 2005, 26):

1. Cyber terorism

National Police Agency of Japan (NPA) mendefiniskan Cyber terorism 
sebagai electronic attacks through computer network against critical infrastructures that have potential critical effects on social and economic ectivities of the nation.

2. Cyber Pornography

Penyebarluasan obscence materials termasuk pornography, indecent expose dan child pornography.

3. Cyber Harassment

Pelecehan seksual melalui email, website, atau chat program

4. Cyber stalking

Crime of stalking melalui penggunaan komputer dan internet

5. Hacking

Penggunaan programming abilities dengan maksud yang bertentangan dengan hukum

6. Carding (credit card fraud)

Melibatkan berbagai macam aktivitas yang melibatkan kartu kredit. Carding muncul ketika seseorang yang bukan pemilik kartu kredit menggunakan kartu kredit tersebut secara malawan hukum.

\section{Karakteristik Cybercrime:}

Berdasarkan beberapa literatur serta praktiknya, cybercrime memiliki beberapa karakteristik yaitu antara lain (Abdul Wahid dan M. Labib, 2005, 76):

1. Perbuatan yang dilakukan secara ilegal, tanpa hak atau tidak eksis tersebut terjadi dalam ruang / wilayah siber/ cyber (cyberspace) sehingga tidak dapat dipastikan yurisdiksi negara mana yang berlaku terhadapnya.

2. Perbuatan tersebut dilakukan dengan menggunakan peralatan apa pun yang terhubung dengan internet

3. Perbuatan tersebut mengakibatkan kerugian materiil maupun immateriil (waktu, jasa, uang, barang, harga diri, martabat, kerahasiaan informasi) yang cenderung lebih besar dibandingkan dengan kejahatan konvensional.

4. Pelakunya adalah orang yang menguasai penggunaan internet beserta aplikasinya.

5. Perbuatan tersebut sering dilakukan secara transnasional / melintas batas negara.

\section{Jerat hukum bagi penyedia jasa} prostitusi melalui media sosial

Prostitusi merupakan masalah hukum dan masalah sosial yang telah ada sejak dulu. Bahkan dikatakan sebagai profesi yang sangat tua dalam perabadan kehidupan manusia. Prostitusi menurut James. A. Inciarti sebagaimana dikutip Topo Santoso merupakan "The Offering Of Sexual Relations For Monetary or Other Gain" (penawaran hubungan seksual untuk memperoleh uang atau keuntungan lainnya). Jadi prostitusi adalah seks untuk pencaharian, terkandung beberapa tujuan yang ingin diperoleh, biasanya berupa uang. Termasuk didalamnya bukan saja persetubuhan tetapi juga setiap bentuk hubungan seksual dengan orang lain untuk mendapat bayaran. Dalam prostitusi terlibat tiga komponen penting yakni pelacur (prostitute). Mucikari atau germo (pimp), dan pelanggan (client) yang dapat dilakukan secara konvensional maupun melalui dunia maya (Topo Santoso, 1997,134).

Jika kita amati salah satu unsur yang terdapat dalam delik KUHP sebagaimana yang mengatur penyebaran pornografi adalah arti "menyiarkan, mempertunjukan, atau menempelkan dengan terang terangan" yaitu:

a. Yang dapat disiarkan adalah misalnya surat kabar, majalah, buku, surat selebaran, atau lainnya yang dibuat dalam jumlah banyak.

b. Mempertunjukkan berarti memperlihatkan kepada orang banyak 
c. Menempelkan berarti melekatkan di suatu tempat yang mudah diketahui oleh orang banyak.

Berdasarkan hal tersebut di atas tentunya media internet sama dengan media massa lain, media massa juga ikut menampilkan berita berita dalam situsnya. Oleh karena itu sama halnya dengan media massa pada umumnya yang berwujud internet dapat dipandang sebagai media berpotensi untuk menyebarluaskan konten negatif. Pornografi anak misalnya di mata para netter dianggap hal sepele walau fatal akibatnya. Menjamurnya warnet membuat motif bisnis mencari keuntungan menjadi raja (Merry Magdalena dan Maswigrantoro Roes Setyadi, 2007; 38).

Pornografi bisa dijadikan konten bisnis yang menggiurkan dengan menampilkan berbagai media porno lewat internet, tentunya hal ini dapat dipersamakan dengan media massa lainnya. Karena internet telah menjadi media efektif dalam penyebaran pornografi (Budi Suhariyanto, 2013; 60).

Ketentuan di dalam KUHP hanya dapat digunakan untuk menjerat penyedia jasa/germo/muncikari berdasarkan ketentuan Pasal 296, Pasal 297, jo. Pasal 506 KUHP: Orang yang menyediakan jasa pornografi sebagaimana disebutkan dalam Pasal 4 ayat (2) UU Pornografi Nomor 44 tahun 2008 yang menyebutkan bahwa "Setiap orang dilarang menyediakan jasa pornografi yang:

a. menyajikan secara eksplisit ketelanjangan atau tampilan yang mengesankan ketelanjangan;

b. menyajikan secara eksplisit alat kelamin;

c. mengeksploitasi atau memamerkan aktivitasseksual; atau

d. menawarkan atau mengiklankan, baik langsung maupun tidak langsung layanan seksual. dapat dipidana dengan pidana penjara paling singkat 6 (enam) bulan dan paling lama 6 (enam) tahun dan/atau pidana denda paling sedikit Rp. 250 juta dan paling banyak Rp. 3 miliar.

Pasal 296 KUHP menyebutkan "Barang siapa dengan sengaja menyebabkan atau memudahkan cabul oleh orang lain dengan orang lain dan menjadikanya sebagai pencaharian atau kebiasaan, diancam dengan pidana penjara paling lama satu tahun empat bulan atau pidana denda paling banyak lima belas ribu rupiah". Pasal ini menentukan bahwa pemidanaan hanya dapat dikenakan bagi dengan orang yang dengan sengaja menyebabkan atau memudahkan perbuatan cabul dengan orang lain, dan menjadikannya sebagai pencaharian atau kebiasaan (Dewi Bunga, Prostitusi Cyer ; 2012, 11).

Pasal yang dapat digunakan pula untuk menjaring mucikari/germo/ penyedia jasa adalah Pasal 297 KUHP mengancam barang siapa yang memperdagangkan wanita dan perdagangan anak laki-laki yang belum dewasa. Menurut Noyon Langemeyer sebagaimana dikutip oleh Sudrajat Bassar bahwa perdagangan wanita harus diartikan sebagai perbuatan yang langsung bertujuan untuk menempatkan seorang perempuan dalam keadaan tergantung dari kemauan orang lain, yang ingin menguasai perempuan itu untuk disuruh melakukan (Dewi Bunga, Prostitusi Cyber, 2012; 30 )perbuatan perbuatan cabul dengan orang ketiga /prostitusi ( Sudrajat Bassar, 1986; 173).

Pasal 506 disebutkan "barang siapa menarik keuntungan dari perbuatan cabul seorang wanita dan menjadikannya sebagai pencaharian, diancam dengan pidana kurungan paling lama satu tahun" (Dewi Bunga, 2012; 12).

Perdagangan orang (human trafficking) sangat mungkin terjadi dalam prostitusi cyber. Perdagangan orang sebagaimana yang dimaksud dalam Pasal 1 angka 1 Undang Undang Nomor 21 
Tahun 2007 Pemberantasan Tindak Pidana adalah "tindakan perekrutan, pengangkutan, penampungan, pengiriman, pemindahan, atau penerimaaan seseorang dengan ancaman kekerasan, penggunaan kekerasan, penculikan, penyekapan, pemalsuan, penipuan, dan penyalahgunaan kekuasaan atau posisi rentan, penjeratan uang atau memberikan bayaran atau manfaat, sehingga memperoleh persetujuan dari orang yang memegang kendali atas orang lain tersebut, baik yang dilakukan di dalam negara maupun antar negara untuk tujuan eksploitasi atau mengakibatkan orang tereksploitasi".

Simon menyatakan bahwa untuk dapat memperdagangkan wanita seorang wanita itu memang diisyaratkan bahwa pelaku harus mempunyai semacam kekuasaan atas wanita tersebut, sehingga ia dapat memperdagangkan, adapun perbuatan perbuatan yang dilakukan pelaku, sebelum ia mempunyai semacam kekuasaan atas wanita yang bersangkutan, dapat dipandang sebagai poging atau percobaan untuk melakukan suatu perdagangan wanita (P,.A.F. Lamintang, dan Theo Lamintang, 2009, 2007).

Jika kata-kata atau tulisan dan gambar yang disiarkan oleh pelacur (prostitute) melalui media sosial memuat kecabulan atau eksploitasi seksual yang melanggar norma kesusilaan dalam masyarakat, maka pelacur (prostitute) tersebut dapat saja dijerat dengan Pasal 27 ayat (1) UU Nomor 11 Tahun 2008 tentang ITE jo. Pasal 45 UU Nomor 19 Tahun 2016 Tentang Perubahan UU No 11 Tahun 2008. Pasal 27 ayat (1) UU No 11 Tahun 2008 Tentang ITE yang merumusakan mengenai perbuatan yang dilarang yakni "Setiap orang dengan sengaja dan tanpa hak mendistribusikan dan atau mentransmisikan dan atau membuat dapat diaksesnya informasi elektronik dan atau dokumen elektronik yang memiliki muatan yang melanggar kesusilaan” (Dewi Bunga, 2012, 28).

Pasal 45 UU Nomor 19 Tahun 2016 tentang Perubahan UU No 11 Tahun 2008 yang isinya :

(1) Setiap Orang yang dengan sengaja dan tanpa hak mendistribusikan dan/atau mentransmisikan dan/atau membuat dapat diaksesnya Informasi Elektronik dan/atau Dokumen Elektronik yang memiliki muatan yang melanggar kesusilaan sebagaimana dimaksud dalam Pasal 27 ayat (1) dipidana dengan pidana penjara paling lama 6 (enam) tahun dan/atau denda paling banyak Rp1.000.000.000,00 (satu miliar rupiah).

(2) Setiap Orang yang dengan sengaja dan tanpa hak mendistribusikan dan/atau mentransmisikan dan/atau membuat dapat diaksesnya Informasi Elektronik dan/atau Dokumen Elektronik yang memiliki muatan perjudian sebagaimana dimaksud dalam Pasal 27 ayat (2) dipidana dengan pidana penjara paling lama 6 (enam) tahun dan/atau denda paling banyak Rp1.000.000.000,00 (satu miliar rupiah).

(3) Setiap Orang yang dengan sengaja dan tanpa hak mendistribusikan dan/atau mentransmisikan dan/atau membuat dapat diaksesnya Informasi Elektronik dan/atau Dokumen Elektronik yang memiliki muatan penghinaan dan/atau pencemaran nama baik sebagaimana dimaksud dalam Pasal 27 ayat (3) dipidana dengan pidana penjara paling lama 4 (empat) tahun dan/atau denda paling banyak Rp750.000.000,00 (tujuh ratus lima puluh juta rupiah).

(4) Setiap Orang yang dengan sengaja dan tanpa hak mendistribusikan dan/atau mentransmisikan dan/atau membuat dapat diaksesnya Informasi 
Elektronik dan/atau Dokumen

Elektronik yang memiliki muatan pemerasan dan/atau pengancaman sebagaimana dimaksud dalam Pasal 27 ayat (4) dipidana dengan pidana penjara paling lama 6 (enam) tahun dan/atau denda paling banyak Rp1.000.000.000,00 (satu miliar rupiah).

(5) Ketentuan sebagaimana dimaksud pada ayat (3) merupakan delik aduan.

Jika iklan yang dilakukan oleh pelacur (prostitute) tersebut disertai foto yang mengandung muatan pornografi, maka ia juga dapat dikenai pidana berdasarkan Pasal 8 jo. Pasal 34 UU Pornografi Nomor 44 Tahun 2008.

\section{Jerat hukum bagi pelaku jasa prostitusi melalui media sosial}

Bagi pekerja seks, mencari pelanggang melalui media online sebenarnya tidak jauh berbeda dengan wanita panggilan lainnya. Dengan media online, mereka mendapatkan beberapa keuntungan. Misalkan saja, pelanggan rata rata berpendidikan. Selain itu bila calon pelanggan tidak berkenan, pekerja seks tidak perlu menghabiskan waktu atau mengeluarkan ongkos untuk datang ke tempat calon pelanggan. Sementara, bagi pelanggan pun cukup menguntungkan mengingat si pekerja seks sudah merinci data diri. Berhubung dengan pekerja seks yang menawarkan diri lewat media internet juga dianggap lebih nyaman. Apalagi kebanyakan para pekerja seks itu berasal dari kalangan menengah ke atas. Menggunakan media internet, bagi sebagian pekerja seks, juga sebagai cara untuk memperpendek mata rantai dagang (http://www.indosiar.com ).

Pasal 34 UU Pornografi merumuskan "setiap orang yang dengan sengaja atau atas persetujuan dirinya menjadi objek atau model yang mengandung muatan pornografi sebagaimana dimaksud dalam Pasal 8 dipidana dengan pidana penjara paling lama 10 (sepuluh) tahun dan atau pidana denda paling banyak Rp. 5.000.000.000,(lima milyar rupiah)' (Adam Chazawi, 2016, 167).

Pasal 8 yang ditunjuk oleh Pasal 34 UU Pornografi merumusakan "setiap orang dilarang dengan sengaja atau atas persetujuan dirinya menjadi objek atau model yang mengandung muatan pornografi"'.

Unsur yang ditunjuk oleh Pasal 34 adalah perbuatan yang sama dengan perbuatan Pasal 8 UU Pornografi. Apabila rumusan Pasal 34 Jo Pasal 8 UU Pornografi dirinci terdiri dari unsur unsur sebagai berikut:

Unsur subjektif:

1. kesalahan; dengan sengaja atau atas persetujuannya

Unsur objektif:

1. perbuatan; menjadi

2. objeknya ; objek atau model yang mengandung muatan pornografi ( Adam Chazawi, 2016, 167).

\section{Penegakan Hukum Prostitusi Cyber Dalam Dimensi Nasional dan Transnasional}

Penegakan hukum merupakan salah satu elemen penting dalam pembangunan hukum. Pembangunan hukum menurut Satjipto Rahardjo memiliki makna ganda. Pertama, ia harus diartikan sebagai suatu usaha untuk memperbarui hukum positif sendiri sehingga sesuai dengan kebutuhan untuk melayani masyarakat pada tingkat perkembangannya yang mutakhir, suatu pengertian yang biasanya disebut sebagai modernisasi hukum. Kedua, ia bisa diartikan sebagai suatu usaha untuk memfungsionalkan hukum dalam masa pembangunan, yaitu dengan cara ikut mengadakan perubahan sosial 
sebagaimana dibutuhkan oleh suatu masyarakat yang sedang membangun (Satjipto Rahardjo, 1983).

Penegakan hukum merujuk pada tindakan penegak hukum dalam menjaring pelaku prostitusi cyber. Upaya penegakan hukum terhadap prostitusi cyber memiliki makna yuridis, sosiologis, dan filosofis bagi information society. Penegakan hukum dengan sendirinya menjamin kepastian hukum bagi para netter saat beraktivitas di cyber space. Supremasi atas kaidah-kaidah hukum nasional dan internasional dapat dijunjung tinggi melalui penegakan hukum yang baik sebab prostitusi cyber merupakan hostis humanis generis (kejahatan adalah musuh umat manusia). Oleh sebab itu setiap warga negara wajib melaksanakan penegakan hukum dan menjalin kerjasama atas penegakan hukum terhadap prostitusi cyber sebagaimana yang tercantum dalam asas au dedere au judicare.

Penegakan hukum terhadap prostitusi cyber juga ditujukan untuk menegakan kembali kaidah kaidah moral yang diakui dan dianut oleh masyarakat internasional dimana setiap orang memiiliki harkat, derajat dan martabat yang sama. Sehingga tidak ada seorang pun yang berhak memperjualbelikan orang lain apalagi mengeksploitasinya. Penegakan hukum oleh penegak hukum secara tidak langsung telah mengukuhkan cyber ethics dan community rules yang telah ada dan terbentuk dalam interaksi para netter (Dewi Bunga, 2012; 65).

\section{PENUTUP}

Prostitusi cyber adalah bagian dari cyber crime yaitu kejahatan yang menggunakan teknologi informasi sebagai fasilitas. Penegakan hukum terhadap kejahatan ini menjadi sangat kompleks karena berada dalam anatomi kejahatan transnasional. Belum optimalnya penegakan hukum terhadap prostitusi online disebabkan karena kualitas dan kuantitas dari penegak hukum yang belum memadai serta sarana dan fasilitas penegak hukum yang memang belum mampu menanggulangi kejahatan di dunia maya. Penegakan hukum tentang prostitusi cyber semakin sulit dilakukan karena ada sebagian masyarakat yang justru mendukung prostitusi cyber dengan menganggapnya sebagai komoditi bisnis. Bahkan ada paradigma pemikiran yang menganggap prostitusi cyber sebagai hal yang wajar dan diharapkan untuk segera dilegalisasikan. 


\section{DAFTAR PUSTAKA}

Ali, Zainuddin, Metode Penelitian Hukum, Jakarta, Sinar Grafika, 2014

Arief, Barda Nawawi dan Muladi, TeoriTeori dan Kebijakan Pidana, Alumni, Bandung, 1992

Arifiyadi, Teguh, Pemberantasan Cybercrime Dengan KUHP, www.depkominfo.go.id

Bassar , Sudrajat, Tindak Pidana Tertentu di Dalam KUHP, Remadja Karya, Bandung, 1986,

Bunga, Dewi, Prostitusi Cyer ; Diskursus Penegakan Hukum Dalam Anatomi Kejahatan Transnasional, Bali, Udayana University Press, 2012,

Chazawi, Adam, Tindak Pidana Pornografi, Sinar Grafika, Jakarta, 2016,

Frommm, Erich, Akar Kekerasan, Pustaka Pelajar, Jakarta, 2000,

http://id.shuoong,com/internet-andtechnologies/website/1851387prostitusi-di-internet

http://media.kompasiana.com/group/newmedia/2010/04/1/bisnismenjanjikan-prostitusi-dalamfacebok/

Lamintang, P,.A.F., dan Theo Lamintang, Delik Delik Khusus Kejahatan Melanggar Norma kesusilaan dan Norma Kepatutan, Sinar Grafika, Jakarta, 2009,

Magdalena, Merry dan Maswigrantoro Roes Setyadi, Cyberlaw Tidak Perlu Takut, Yogyakarta, Andi 2007

Mansur, Dikdik M. Arief dan Elisatris Gultom, Cyber law (Aspek
Hukum Teknologi Informasi), Bandung, Refika Aditama, 2005,

Marpaung, Leden ,Kejahatan Terhadap Kesusilaan, Sinar Grafika, Jakarta, 1996,

Maskun, Kejahatan Siber ; Cyber Crime, Kencana Prenada Media Gruop, Jakarta, 2013,

Raharjo, Agus, Cyber Crime ; Pemahaman dan Upaya Pencegahan Kejahatan Berteknologi, Citra Aditya, Bandung, 2002,

Raharjo, Satjipto, Hukum dan Masyarakat, Angkasa, Bandung, 1980, , Hukum dan Perubahan Sosial, Alumni, Bandung, 1983

Santoso, Topo, Seksualitas dan Hukum Pidana, Jakarta, Ind-Hill-Co, 1997,

Suhariyanto, Budi, Tindak Pidana Teknologi Informasi (Cybercrime) Urgensi Pengaturan dan Celah Hukumnya, Depok, Rajagrafindo Persada, 2013,

Sutarman, Cyber Crime Modus Operandi dan Penanggulangannya, Yogyakarta, Laksbang Pressindo ,2007

Suratman dan Philips Dillah, Metode Penelitian Hukum, Bandung, Alfabetha, 2012,

Soekanto, Soerjono, Pokok Pokok Sosiologi Hukum, Rajawali Press, Jakarta, 1980.

Wahid, Abdul dan M. Labib, Kejahatan Mayantara (Cybercrime), Bandung, Refika Aditama, 2005, 